\title{
The effect of C-reactive protein, procalcytonine, neutrophil/ lymphocyte levels on mortality and duration of hospital stay in pneumonia
}

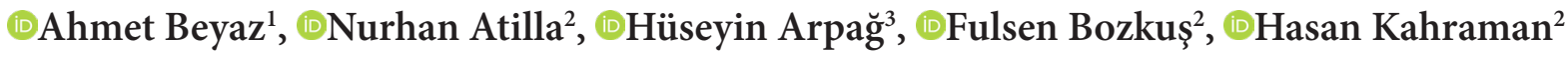 \\ (D)Fatih Alper Ŭguz ${ }^{4}$ \\ ${ }^{1}$ Mut Government Hospital, Department of Chest Diseases, Mersin, Turkey \\ ${ }^{2}$ Kahramanmaras Sutcu Imam University Medicine Faculty, Department of Chest Diseases, Kahramanmaras, Turkey \\ ${ }^{3}$ Batman Medical Park Hospital, Department of Chest Diseases, Batman, Turkey \\ ${ }^{4}$ Mersin Government Hospital, Department of Chest Diseas, Mersin, Turkey
}

Cite this article as: Beyaz A, Atilla N, Arpağ H, Bozkuş F, Kahraman H, Uğuz FA. The effect of C-reactive protein, procalcytonine, neutrophil/ lymphocyte levels on mortality and duration of hospital stay in pneumonia. Anatolian Curr Med J 2021; 3(1); 15-19.

\begin{abstract}
Aim: The aim of this study is to investigate the effects of procalcytonin (PCT), C-reactive protein (CRP) and neutrophil to lymphocyte ratio (NLR) on the mortality and duration of hospital stay in patients diagnosed with pneumonia.

Material and Method: The study consists of 111 cases of pneumonia followed in our chest diseases service and intensive care unit between 2017 to 2018. Collected data included demographic information, NLR, PCT, CURB-65 scores. The data were evaluated by parametric tests (paired sample T test, independent sample T test). Chi-square test was used in order to compare categorical variables. P value $\leq 0.05$ was considered statistically significant.

Results: A statistically significant positive correlation was detected between PCT and NLR ( $<<0.001 ; \mathrm{r}=0.343$ ), PCT and CRP ( $\mathrm{p}<0.001 ; \mathrm{r}=0.502)$, NLR and CRP $(\mathrm{p}<0.001 ; \mathrm{r}=0.427)$. There was a statistically significant correlation between mortality and CRP $(\mathrm{p}<0.001 ; 0.427)$, mortality and PCT $(\mathrm{p}<0.001 ; \mathrm{r}=0.343)$ and mortality and NLR $(\mathrm{p}=0.013 ; \mathrm{r}=0.235)$. There was a statistically significant correlation between duration of hospital stay and PCT $(p=0.036 ; r=0.199)$ duration of hospital stay and $\operatorname{NLR}(p=0.030 ; r=0.206)$ but not with duration of hospital stay and CRP $(p=0.298 ; r=0.102)$.

Conclusion: Besides PCT and CRP, NLR can also be used for prognosis estimation in pneumonia patients.

Keywords: C-reactive protein, neutrophil lymphocyte ratio, procalcytonin, pneumonia
\end{abstract}

\section{INTRODUCTION}

Mortality rates in community-acquired pneumonia is seen around $1 \%$ in outpatients, these rates increase to $50 \%$ in inpatients, especially those in need of intensive care (1). Early diagnosis and treatment is quite important in pneumonia. But the microbiological factor causing pneumonia is often undetectable, it is necessary to correctly predict the possible factors for empirical treatment $(2,3)$. Empirical treatment for the etiological agent should be started after evaluating the anamnesis, clinical, physical examination, laboratory and radiological findings as a whole in pneumonia patients.

Procalcytonin (PCT) is a polypeptide consisting of 116 amino acids that increase as a result of inflammatory stimulation and exhibit cytokine-like behavior. While it is found to be undetectable in plasma of healthy people, non-infectious inflammatory diseases such as autoimmune disease, severe viral, bacterial, parasitic and fungal infections, cause to rise PCT levels $(4,5)$.

Since the negative predictive value of PCT is $99 \%$ in bacterial and systemic infections, looking at the PCT value in intensive care can also be very important to prevent inappropriate antibiotic initiation (6).

C-reactive protein (CRP), the first identified acute phase protein, was discovered in 1930 as the protein that reacts with the C-polysaccharide of the S. pneumoniae cell wall (7).CRP value may increase in infections, inflammatory 
conditions, tissue damage etc. In addition, despite the bacterial infection, it may be low in the first 12 hours. If bacterial infection is considered clinically, it should be followed up in series. So, the CRP response is not an infection-specific finding. Therefore, it is extremely important to consider it together with clinical evaluation.

Since the physiological response of circulating leukocytes to stress causes an increase in neutrophil count and a decrease in lymphocyte count, it is used as an indicator of inflammation in intensive care units $(8,9)$. During the inflammatory response that occurs, the rates of circulating leukocytes change. Neutrophilia is accompanied by relative lymphopenia. This causes an increase in neutrophil lymphocyte ratio (NLR). Neutrophil lymphocyte ratio can increase in many inflammatory events such as acute abdominal events, mesenteric ischemia, peptic ulcer perforation, acute cholecystitis, lymph node metastasis in some cancers, pulmonary embolism, acute ischemic stroke, acute coronary syndromes, rheumatoid arthritis and ankylosing spondylitis. Therefore, NLR can be considered as a simple and low-cost marker for evaluating the inflammatory response.

In our study, we aimed to investigate the correlation of CRP, PCT and NLR serum levels in patients diagnosed with pneumonia and to determine the clinical predictive values of these parameters in terms of mortality and duration of hospital stay.

\section{MATERIAL AND METHOD}

The study was conducted in accordance with the principles of Helsinki Declaration. The study was carried out with the permission of Clinical Researches Ethics Committee of Kahramanmaraş Sütçü İmam University (Permission granted: 22.11.2017, Decision no: 2017/19-07).

One hundred and eleven community-acquired pneumonia patients which were radiologically and clinically compatible with bacterial pneumonia, hospitalized by chest diseases outpatient clinic and emergency outpatient clinic were included in this study.

The results of the laboratory tests taken on the 1st day of hospitalization were used. Hospitalization decision of the patients was made according to the CURB-65 score. CRP, PCT, neutrophil, lymphocyte parameters were already exists in our routine tests. The duration of hospital stay, mortality/recovery status were recorded.

\section{Statistical Analysis}

The data were analyzed with SPSS (Statiscal Package for Social Sciences) for Windows 16.0. Descriptive statistics data reported by percentage or mean \pm SD. The data were normally distributed, evaluated by parametric tests (Paired sample T test, Independent sample T test). The chi-square test was used in order to compare categorical variables. $\mathrm{P}$ value $\leq 0.05$ was considered statistically significant.

\section{RESULTS}

One hundred and eleven patients were included in our study. The average age of our patients was $72.08 \pm 16.12$. There wasn't any statistically significant correlation between age and mortality ( $\mathrm{p}=0.10)$. Forty-six $(41.4 \%)$ of our patients were female and $65(58.6 \%)$ were male. When evaluating between gender and mortality, we didn't find any statistically significant correlation between gender and mortality $(p=0.933)$.

Twenty-three of our patients (20.7\%) were hospitalized and followed as aspiration pneumonia. When evaluating between aspiration pneumonia and mortality, a statistically significant positive correlation was found between aspiration anamnesis and mortality $(\mathrm{p}=0.003)$.

Nine $(8.1 \%)$ of our patients had pleural effusion. At least one comorbidity was present in 80 (72.7) of our patients. Distribution of our additional diseases were as follows; 36 (32.4\%) cerebrovascular diseases (CVD), 16 (14.4\%) chronic obstructive pulmonary disease (COPD), 15 (13.5\%) congestive heart failure (CHF), 13 (11.7\%) diabetes mellitus (DM), 16 (14.4\%) chronic kidney failure (CKF), 7 (6.3\%) asthma and 2 $(1.8 \%)$ pulmonary embolism. When our patients with comorbid conditions were evaluated in terms of the effects of comorbid conditions on mortality; there was a statistically significant positive correlation in terms of neurological diseases $(\mathrm{p}=0.013)$.

Blood culture was taken from 43 (38.7\%) patients and growth was seen in 21 of them. Reproduction was seen in the sputum culture of our $35(31.5 \%)$ patients. When evaluated in terms of their outcomes, $84(75.7 \%)$ patients were discharged while 27 (24.3\%) of our patients had exitus.

A statistically significant positive correlation was detected between PCT and NLR $(\mathrm{p}<0.001 ; \mathrm{r}=0.343)$ PCT and CRP $(\mathrm{p}<0.001 ; \mathrm{r}=0.502)$ (Figure 1,2). There was also a statistically significant positive correlation between NLR and CRP $(\mathrm{p}<0.001 ; \mathrm{r}=0.427)$ (Figure 3).

There was a statistically significant correlation between mortality and CRP $(\mathrm{p}<0.001 ; 0.427)$, PCT $(\mathrm{p}<0.001$; $\mathrm{r}=0.343)$, and NLR $(\mathrm{p}=0.013 ; \mathrm{r}=0.235)$ (Table 1). 


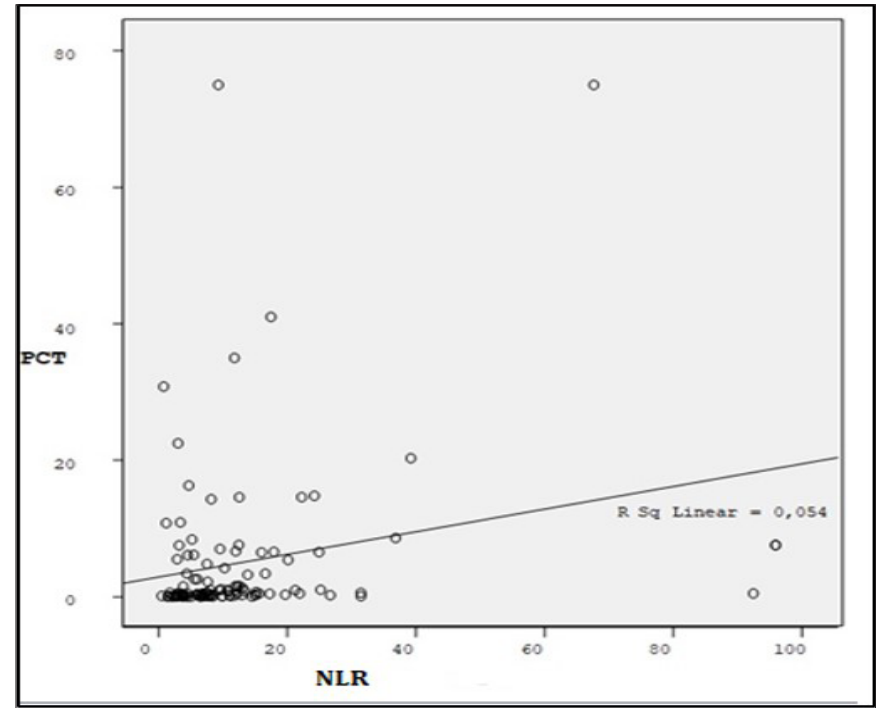

Figure 1. Correlation between PCT and NLR PCT: Procalcytonin, NLR: Neutrophil to lymphocyte ratio

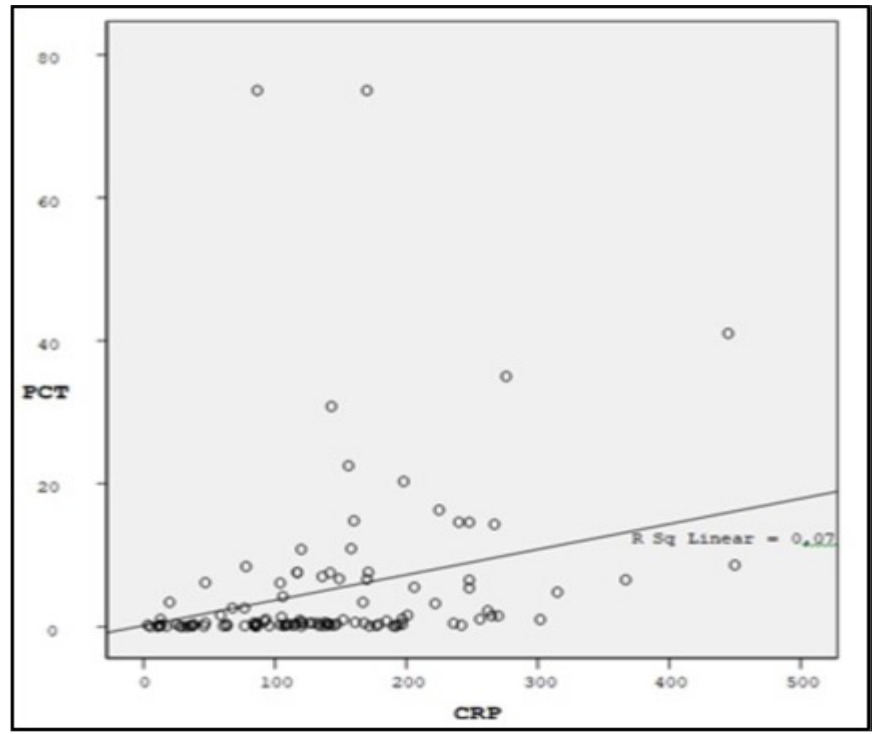

Figure 2. Correlation between PCT and CRP PCT: Procalcytonin, $\mathrm{CRP}=\mathrm{C}$-reactive protein

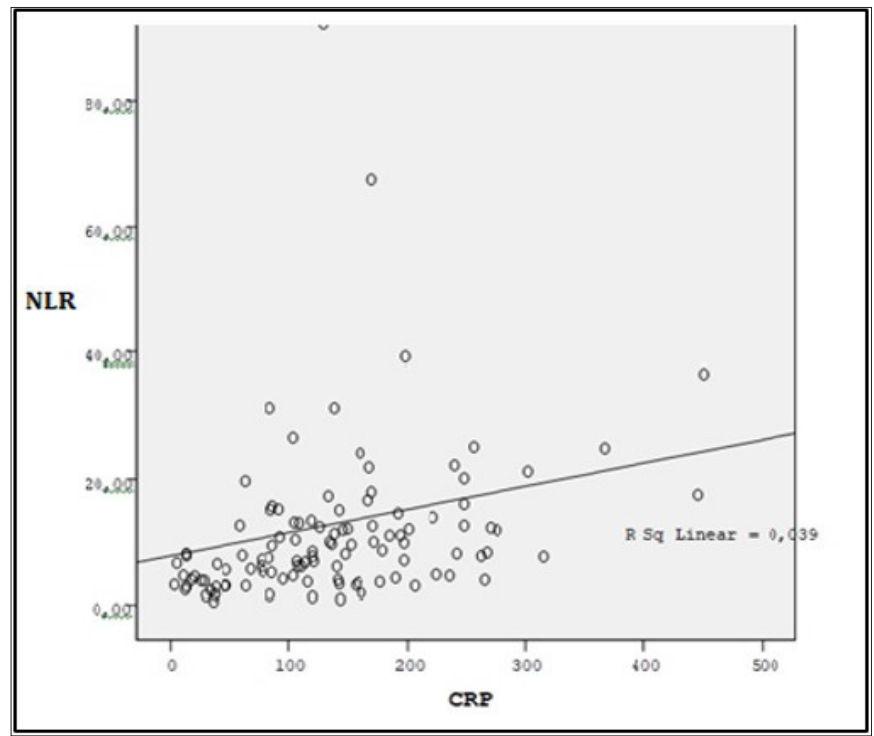

Figure 3. Correlation between NLR and CRP

PCT: Procalcytonin, $\mathrm{CRP}=\mathrm{C}$-reactive protein
There was no significant correlation between duration of hospital stay and CRP ( $\mathrm{p}=0.298 ; \mathrm{r}=0.102)$, PCT $(\mathrm{p}=0.036 ; \mathrm{r}=0.199)$, and NLR $(\mathrm{p}=0.030 ; \mathrm{r}=0.206)$ (Table 1). Statistically significant positive correlation was also found between the CURB-65 scores and mortality $(\mathrm{p}<0.001 ; \mathrm{r}=0.400)$.

Table 1. Relationship between CRP, PCT, NLR values and hospital stay and mortality

\begin{tabular}{|lcccc|}
\hline & \multicolumn{2}{c}{ Hospital stay } & \multicolumn{2}{c|}{ Mortality } \\
\hline & $\mathbf{p}$ & $\mathbf{r}$ & $\mathbf{p}$ & $\mathbf{r}$ \\
CRP & 0.288 & 0.102 & $<0.001$ & 0.427 \\
PCT & 0.036 & 0.199 & $<0.001$ & 0.334 \\
NLR & 0.030 & 0.206 & 0.013 & 0.235 \\
\hline NLR: Neutrophil to lymphocyte ratio, CRP= C-reactive protein, PCT: Procalcytonin \\
\hline
\end{tabular}

\section{DISCUSSION}

Among the most common infections in the hospital, pneumonia is the most common cause of mortality. In cases with pneumonia in our country, the crude mortality rate ranges between $30-87 \%(10,11)$. Although this rate does not show pneumonia-related mortality, it was shown in a study that the development of pneumonia increased mortality in intensive care unit patients by 3 times (12). In studies conducted worldwide, it is reported that mortality is between $5.1 \%$ and $57.3 \%$ according to the severity of pneumonia. In the study of Kothe et al., 30-day mortality was found as $6.3 \%$ (13). Mortality rate was reported as $10.4 \%$ in a study conducted by Sever et al. (14) which included 72 patients. The mortality rate of our study was 27 (24.3\%). The average age of our patients was $72.08 \pm 16.12$. Twenty of the 27 patients who died were over 75 years old. The reason why our mortality rate is slightly higher compared to other studies may be that our average age is high.

In our study, 36 of our patients had neurological diseases (32.4\%), 16 (14.4\%) had CKF, 15 (13.5\%) had CHF, 13 (11.7\%) had DM, 7 (6.3\%) had asthma, 2 (1.8\%) had pulmonary embolism. It was observed that our comorbidity rates were generally similar to other studies. In a study by Bircan et al. (15) comorbid diseases were found in 41 (44.1\%) cases, most frequently COPD (23.7\%), DM (17.2\%) and cardiovascular diseases (15.1\%). In the study conducted by Fukuyama et al. (16) chronic respiratory diseases $(39.6 \%), \mathrm{CHF}(25 \%)$ and $(23.8 \%)$ were found. In the study of Yandiola et al. (17) COPD, cardiovascular diseases and CVD were found most frequently. In a multicentre study by Köksal et al. (18) COPD was identified as the underlying disease in $42.7 \%$ of 218 patients who were followed up inpatient or outpatient. This was followed by hypertension (29.8\%), CHF (9.6\%) and DM (8.7\%). Similarly, in another study involving 67 patients who were hospitalized inpatient or outpatient, the 
comorbidity rate was reported to be $34 \%$ (19). In the study conducted by Doruk et al. (20) cerebrovascular disease (39.6\%) was detected as the most common comorbid disease in 48 cases, followed by COPD (35.4\%), CHF (25\%), malignancy (14.6\%) and other diseases (14.6\%) is.

In our study, the correlation between mortality and procalcytonine and CURB-65 was similar to other studies. We did not have any patient who developed mortality from $16(14.4 \%)$ patients in the low-risk group according to CURB-65. Mortality was 27 (28\%) in 95 (85.5\%) patients in the high-risk group according to CURB-65. In a study of 3181 patients who applied to the emergency department, PSI and CURB-65 scoring systems were reported to be successful in predicting mortality and identifying patients with a low mortality risk (21). Man et al. (22) reported the mortality rate as $3 \%$ in the low-risk group, $19.50 \%$ in the high-risk group, $2.9 \%$ in the low-risk group and $22.1 \%$ in the high-risk group with CURB-65. In the study conducted by Shah et al., the validity of PSI and CURB 65 scoring systems were evaluated in community-acquired pneumonia patients, and it was found that PSI and CURB 65 were equally sensitive in determining the probability of death, but the specificity of CURB 65 was higher than PSI (23).

Treatment should be started early and with the right agent to reduce pneumonia deaths. Therefore, the use of markers specific for bacterial infections is essential in diagnosis and follow-up. It has been demonstrated that PCT is a good indicator in patients with pneumonia. It has been reported that the sensitivity of PCT is particularly high in sepsis (24).

In our study, a correlation was observed between NLR and PCT and also between NLR and CRP. In addition, NLR had a statistically significant positive correlation with mortality and duration of hospital stay. For this reason, NLR can be considered as a beneficial inflammatory marker in community-acquired bacterial pneumonia patients. It can even be used to predict the prognosis of these patients.

Limitations: Pneumonia severity index could be used in addition to CURB-65 to determine the severity of pneumonia. SOFA or APACHE II scores of patients especially those hospitalized in the intensive care unit could also be included in study parameters.

\section{CONCLUSION}

As a result, CRP, PCT and NLR values were observed to be correlated in pneumonia patients. We think that NLR values could be used as an infection parameter like CRP and PCT in pneumonia patients. Using scoring systems together with NLR values may be guide to predict mortality. More studies are needed on this subject.

\section{ETHICAL DECLARATIONS}

Ethics Committee Approval: The study was carried out with the permission of Clinical Researches Ethics Committee of Kahramanmaraş Sütçü İmam University (Permission granted:22.11.2017, Decision no: 2017/1907).

Informed Consent: All patients signed the free and informed consent form.

Referee Evaluation Process: Externally peer-reviewed.

Conflict of Interest Statement: The authors have no conflicts of interest to declare.

Financial Disclosure: The authors declared that this study has received no financial support.

Author Contributions: All of the authors declare that they have all participated in the design, execution, and analysis of the paper, and that they have approved the final version.

\section{REFERENCES}

1. Özlü T, Bülbül Y, Ozsu S. Community-acquired pneumonia based on the Turkish national data. Tuberk Toraks 2007; 55: 191-212.

2. Bates JH, Campbell GD, Barron AL, et al. Microbial etiology of acute pneumonia in hospitalized patients. Chest 1992; 101: 100512.

3. Fang GD, Fine M, Orloff J, et al. New and emerging etiologies for communityacquired pneumonia with implications for therapy; a prospective multicenter study of 359 cases. Medicine 1990; 69: 307-16.

4. Assicot M, Gendrel D, Carsin H, Raymond J, Guilbaud J, Bohuon C. High serum procalcytonine concentrations in patients with sepsis and infection. Lancet 1993; 341: 515-8.

5. Carrol ED, Thomson AP, Hart CA. Procalcytonine as a marker of sepsis. Int J Antimicrob Agents 2002; 20: 1-9.

6. Shehabi Y, Seppelt I. Pro/Con debate: Is procalcytonine useful for guiding antibiotic decision making in critically ill patients? Critical Care 2008; 12: 211.

7. Thompson D, Pepys MB, Wood SP. The physiological stucture of human $\mathrm{C}$ - reactive protein and its complex with phosphocholine. Structure 1999; 7: 169-77.

8. Jilma B, Blann A, Pernerstorfer T, et al. Regulation of adhesion molecules during human endotoxemia. No acute effects of aspirin. Am J Respir Crit Care Med 1999; 159: 857-63.

9. Zahorec R. Ratio of neutrophil to lymphocyte counts-Rapid and simple parameter of systemic inflammation and stress in critically ill. Bratisl Lek Listy 2001; 102: 5-14.

10. Şimşek S, Yurtseven N, Gerçekoğlu H, et al. Ventilator associated pneumonias in a cardiothoracic surgery centre postoperative intensive care unit. J Hosp Infect 2001; 47: 321-4.

11. Aybar M, Topeli A. Dahili yoğun bakım ünitesinde ventilatörle ilişkili pnömoni epidemiyolojisi. Yoğun Bakım Derg 2001; 1: 41-6.

12. Çevik MA, Yılmaz GR, Erdinç FŞ, et al. Nöroloji Yoğun Bakım Ünitesinde mortalite ile ilişkili faktörler ve nozokomiyal enfeksiyonla mortalitenin ilişkisi. Yoğun Bakım Derg 2001; 1: 4755.

13. Cazzola M, Centanni S, Blasi F. Have guidelines for the management of community-acquired pneumonia influenced outcomes? Respir Med 2003; 97: 205-11. 
14. Sever F, Kömüs N, Esen N, Gündüz AT, Öktem MA, Cımrın AH. Türkiye'de toplum kökenli pnömoni etyoloji ve epidemiyolojisi. Turk Toraks Derg 2013; 14: 5-10.

15. Bircan A, Kaya Ö, Gökırmak M, Öztürk Ö, Sahin Ü, Akkaya A. Toplum kökenli pnömonilerin ağırlı̆̆ının değerlendirilmesinde C-reaktif protein, lökosit sayısı ve eritrosit sedimentasyon hızının yeri. Tuberk Toraks 2006; 54: 22-9.

16. Fukuyama $\mathrm{H}$, Ishida, Tachibana $\mathrm{H}$, et al. Validation of scoring systems for predicting severe community-acquired pneumonia. Intern Med 2011; 50: 1917-22.

17. Yandiola PPE, Capelastegui A, Quintana J, et al. prospective comparison of severity scores for predicting clinically relevant outcomes for patients hospitalized with community-acquired pneumonia. Chest 2009; 135: 1572-9.

18. Murphy TF, Parameswaran GI. Moraxella catarrhalis, a human respiratory tract pathogen. Clin Infect Dis 2009; 49: 124-31.

19. Bircan A, Sutcu R, Gokırmak M. Total antioxidant capacity and C-reactive protein levels in patients with community-acquired pneumonia. Turk J Med Sci 2008; 38: 537-44.

20. Doruk S, Bulaç S, Sevinç C, Bodur HA, Yilmaz A, Erkorkmaz U. Severity scores and factors related with mortality in cases with community-acquired pneumonia patients in intensive care unit. Tuberk Toraks 2009; 57: 393-400.

21. Aujesky D, Auble TE, Yealy DM, et al. Prospective comparison of three validated prediction rules for prognosis in communityacquired pneumonia. Am J Med 2005; 118: 384-92.

22. Man SY, Lee N, Ip M, et al. Prospective comparison of three predictive rules for assessing severity of community acquired pneumonia in Hong Kong. Thorax 2007; 62: 348-53.

23. Shah BA, Ahmed W, Dhobi GN, Shah NN, Khursheed SQ, Haq I. Validity of pneumonia severity index and CURB-65 severity scoring systems in community acquired pneumonia in an Indian setting. Indian J Chest Dis Allied Sci 2010; 52: 9-17.

24. Monneret G, Labaune JM, Isaac C, Bienvenu F, Putet G, Bienvenu J. Procalcytonine and C-reactive protein levels in neonatal infections. Acta Paediatr 1997; 86: 209-12. 